\title{
Adequate Dosage of Norepinephrine Infusion Combined with Goal-Directed Fluid Therapy During General Anesthesia May Improve Elderly Patients' Postoperative Outcome Undergoing Lumbar Spinal Fusion
}

\section{Fan Wu}

Department of Anesthesiology, Xuanwu Hospital,Capital Medical University, Beijing,China. Department of Anesthesiology, The Affiliated Hospital of Inner Mongolia Medical University, Hohhot,Inner Mongolia,P.R. China

\section{Tao Liang}

Department of Anesthesiology ,Sanbo Brain Hospital, Capital Medical University

Jie Wu

Department of Anesthesiology, Xuanwu Hospital,Capital Medical University, Beijing,China

\section{Wei Xiao}

Department of Anesthesiology, Xuanwu Hospital,Capital Medical University, Beijing,China

\section{Long Fan}

Department of Anesthesiology, Xuanwu Hospital,Capital Medical University, Beijing,China

\section{Huiqun Fu}

Department of Anesthesiology, Xuanwu Hospital,Capital Medical University, Beijing,China

\section{Yanhui Ma}

Department of Anesthesiology, Xuanwu Hospital,Capital Medical University, Beijing,China

Tianlong Wang ( $\sim$ w_tl5595@hotmail.com)

Capital medical university

\section{Research}

Keywords: Elderly patients, Posterior lumbar spinal fusion, General anesthesia, Norepinephrine, Complication, Postoperative outcome

Posted Date: May 27th, 2020

DOI: https://doi.org/10.21203/rs.3.rs-28088/v1

License: (c) (1) This work is licensed under a Creative Commons Attribution 4.0 International License. Read Full License 


\section{Abstract}

Background: Norepinephrine is used to prevent anesthesia-related disorders in elderly patients. However, optimal dosage that improve the postoperative outcome undergone lumbar spinal fusion is unknown.

Methods: A total of 108 elderly patients were randomized into three groups of norepinephrine infusion as $0.030 \mu \mathrm{g} \cdot \mathrm{kg}^{-1} \cdot \mathrm{min}^{-1}, 0.060 \mu \mathrm{g} \cdot \mathrm{kg}^{-1} \cdot \mathrm{min}^{-1}$ and $0.090 \mu \mathrm{g} \cdot \mathrm{kg}^{-1} \cdot \mathrm{min}^{-1}$. The hemodynamics and related parameters were monitored at the entrance to the operation room $\left(T_{0}\right), 15$ min following anesthesia induction $\left(T_{1}\right), 60$ min after surgical incision $\left(T_{2}\right)$, and immediately after surgery $\left(T_{3}\right)$, respectively. The primary outcome was set as the incidence of postoperative complications and wound infections. The secondary outcomes were recorded by the incidence of nausea and vomiting, the time of first flatus, first ambulation, first intake and postoperative hospital stay.

Results: Finally, 90 patients were recruited into the clinical trial, with 30 in each group. The incidence of delayed wound healing and infection were increase with the dose of $0.030 \mu \mathrm{g} \cdot \mathrm{kg}^{-1} \cdot \mathrm{min}^{-1}$ compared to others $\left(0.030 \mu \mathrm{g} \cdot \mathrm{kg}^{-1} \cdot \mathrm{min}^{-1}\right.$ vs. $0.060 \mu \mathrm{g} \cdot \mathrm{kg}^{-1} \cdot \mathrm{min}^{-1}$ vs. $0.090 \mu \mathrm{g} \cdot \mathrm{kg}^{-1} \cdot \mathrm{min}^{-1}: 33.3 \%$ vs. $10 \%$ vs. $10 \%, P=$ $0.024 ; 26.7 \%$ vs. $6.7 \%$ vs. $6.7 \%, P=0.031)$. Intraoperative total fluid volume and crystalloids, colloids volume in $0.030 \mu \mathrm{g} \cdot \mathrm{kg}^{-1} \cdot \mathrm{min}^{-1}$ group were significantly higher than 0.060 and $0.090 \mu \mathrm{g} \cdot \mathrm{kg}^{-1} \cdot \mathrm{min}^{-1}$. The incidence of intraoperative hypotension effectively decreased in $0.060 \mu \mathrm{g} \cdot \mathrm{kg}^{-1} \cdot \mathrm{min}^{-1}$ and $0.090 \mu \mathrm{g} \cdot \mathrm{kg}^{-1} \cdot \mathrm{min}^{-1}$ compared to $0.030 \mu \mathrm{g} \cdot \mathrm{kg}^{-1} \cdot \mathrm{min}^{-1}(6.7 \% \mathrm{vs} 33.3 \%, P=0.01,3.3 \% \mathrm{vs} .33 .3 \%, P=0.003)$. The frequency of bradycardia in $0.090 \mu \mathrm{g} \cdot \mathrm{kg}^{-1} \cdot \mathrm{min}^{-1}$ group's patients was significantly higher than that in the dosage $0.030 \mu \mathrm{g} \cdot \mathrm{kg}^{-1} \cdot \mathrm{min}^{-1}$ group $(3 \% v s 26 \%, P=0.026)$ and $0.060 \mu \mathrm{g} \cdot \mathrm{kg}^{-1} \cdot \mathrm{min}^{-1}$ group $(3 \% v s .6 .7 \%, P=0.038)$. Patients with $0.060 \mu \mathrm{g} \cdot \mathrm{kg}^{-1}$. $\mathrm{min}^{-1}$ had earlier first intaking by 1.4 hours and first flatus by 1.1 hours. Overall, Postoperative hospital stay was reduced by around 1 day in the $0.060 \mu \mathrm{g} \cdot \mathrm{kg}^{-1} \cdot \mathrm{min}^{-1}$ and $0.090 \mu \mathrm{g} \cdot \mathrm{kg}^{-}$ ${ }^{1} . \mathrm{min}^{-1}$ group among three groups (6.0 vs. 6.2 vs. 7.1 days, $\left.P=0.066\right)$.

Conclusion: The $0.060 \mu \mathrm{g} \cdot \mathrm{kg}^{-1} \cdot \mathrm{min}^{-1}$ dosage of norepinephrine infusion combined with goal-directed fluid therapy can improve the elderly patients' postoperative outcome and accelerate their rehabilitation process.

Clinical Trial Registration: Identifier ChiCTR-1900021309, Registration date: September 19, 2018; www.chictr.org.cn.

\section{Background}

Spine degenerative disease is very common in elderly patients. The surgical intervention is one of treatment option to ameolinate symptoms and improve the quality of life. General anesthesia is usually administered in elderly patients for lumbar spinal fusion surgery [1]. Intraoperative hypotension is a common complication, and inadequate treatment will result in higher incidence of complications during general anesthesia and adverse postoperative outcome. The ongoing research aims to develop an effective method for the prevention and management of intraoperative hypotension. Whether or not the fluid therapy combined with vasopressors is the ideal approach has not yet been determined. Reportedly, prolonged surgery, intraoperative blood loss and volume of crystalloid fluid resuscitation increased are harmful to the 
early rapid recovery of patients [2]. The goals of intraoperative fluid management are to maintain central euvolemia and minimize excessive salt and water infusion [3]. Excessive fluid loading in elderly patients will disrupt glycocalyx, which is a carbohydrate-rich layer lining the endothelium that plays a crucial role in maintaining endothelial integrity. Destruction of endothelial glycocalyx can result in tissue edema and adverse outcome [4].

Pulse pressure variation (PPV) is used as an accurate position indicator on the Frank-Starling curve. The arterial PPV induced by mechanical ventilation is a reliable and accurate predictor of fluid responsiveness in the patients under general anesthesia. This indicator can predict the adverse hemodynamic effects of fluid depletion, as well as the beneficial effects of fluid loading [5]. Norepinephrine is characterized by aadrenergic agonistic activity in addition to a weak $\beta$-adrenergic agonistic activity [6]. The compound does not reduce the heart rate and cardiac output, similar to that of phenylephrine. The prophylactic administration of norepinephrine to prevent and control hypotension during general anesthesia for lumbar spinal fusion surgery in elderly patients is a novel concept, but the literature is scarce. Therefore, the present research aimed to investigate the effectiveness of prophylactic adequate dosage of norepinephrine infusion in preventing intraoperative fluid overload risk and improving postoperative outcoime in elderly patients undergone lumbar spinal fusion during general anesthesia with a sequential allocation trial. The main objective was to determine the adequate dosage of norepinephrine infusion $\left(0.030 \mu \mathrm{g} \cdot \mathrm{kg}^{-1} \cdot \mathrm{min}^{-1}\right.$, $0.060 \mu \mathrm{g} \cdot \mathrm{kg}^{-1} \cdot \mathrm{min}^{-1}, 0.090 \mu \mathrm{g} \cdot \mathrm{kg}^{-1} \cdot \mathrm{min}^{-1}$ ) against intraoperative fluid overload and consequent postoperative complications.

\section{Materials And Methods Research Design}

The single center trial took a prospective, randomized, parallel group design. The present research was conducted at Department of Anesthesiology, Affiliated Hospital of Inner Mongolia Medical University (IHIMMU) (Hohhot, China) from September first, 2018 to April first,2019. The research protocol was approved by the hospital's Ethics Committee (KY2018022), which was performed in accordance with the Declaration of Helsinki (2014). After approval, the clinical research was registered in the Chinese Clinical Trial Registry (website: www.chictr.org.cn, ChiCTR-1900021309) and adhered to CONSORT guidelines. After enrolment and before start of the experiments, the researchers clearly explained the experimental procedures, the objectives of the study, possible benefits, and side effects of the study to all elderly patients and obtained the signed consent form for participation in the research. Verbal and written informed consents were obtained from all the included patients.

\section{Patients}

Elderly patients with lumbar disk herniation or lumbar spondylolisthes undergone elective lumber spinal fusion were recruited into the research. The type of surgery was selected as posterior lumbar discectomy combined with pedicle screw fixation and intertransverse fusion. The inclusion criteria was the elderly 
patients with ASA grade less than III and aged $60 \sim 85$ years. The exclusion criteria was confined as patients refusal to participate in the research at any time. Patients with bradycardia (heart rate $<50 \mathrm{bpm}$ ), cardiac morbidities, heart block greater than the first degree, abnormal liver or renal function, hyperthyroidism, vascular diseases and bowel disease (e.g, ulcerative colitis, Crohn's disease, and irritable bowel syndrome) were excluded.

\section{Randomization and Blinding}

Randomization was achieved by a statistician using an online random number generator. Patient codes were placed into sequentially numbered sealed opaque envelopes by a research assistant who was not involved in the research. An anesthesiologist resident not involved in the patient management was responsible for opening the envelope and preparing the research's drug according to the instructions in each envelope. All surgeons, patients, attending anesthesiologists, nurses and follow-up anesthesiologists were blinded to group assignments.

\section{Interventions}

At the holding area, an IV line was established with an18-gauge IV cannula in the forearm, and an infusion of Ringer's lactate (RL) solution was started at a minimal rate to keep the vein open. The baseline mean arterial pressure (MAP) was measured three times in the supine position and average computed. The readings were recorded 1 min apart for the assessment of the noninvasive blood pressure with an automated device. One hundred and eight patients were randomly divided into three groups by dosage of norepinephrine infusion: $0.030 \mu \mathrm{g} \cdot \mathrm{kg}^{-1} \cdot \mathrm{min}^{-1}, 0.060 \mu \mathrm{g} \cdot \mathrm{kg}^{-1} \cdot \mathrm{min}^{-1}$, and the $0.090 \mu \mathrm{g} \cdot \mathrm{kg}^{-1} \cdot \mathrm{min}^{-1} \mathrm{group}(\mathrm{n}=$ 36). All patients was continuouslly infused norepinephrine by the dosage of $0.030 \mu \mathrm{g} \cdot \mathrm{kg}^{-1} \cdot \mathrm{min}^{-1}$, $0.060 \mu \mathrm{g} \cdot \mathrm{kg}^{-1} \cdot \mathrm{min}^{-1}$ and $0.090 \mu \mathrm{g} \cdot \mathrm{kg}^{-1} \cdot \mathrm{min}^{-1}$, respectively before the initiation of general anesthesia.

In the operating room, standard monitoring were performed by ECG, Heart Rate, noninvasive blood pressure, and pulse oximetry $\left(\mathrm{SpO}_{2}\right)$. A radial artery cannula was inserted, and the pressure transducer was set to zero at the mid-axillary level to ambient pressure. The patients in three groups were given a predefined dosage of norepinephrine infusion before the initiation of general anesthesia. Then, general anesthesia was induced with fentanyl (20 to $30 \mathrm{\mu g}^{-1} \cdot \mathrm{kg}^{-1} \mathrm{IV}$ ), lidocaine $\left(1.5 \mathrm{mg}^{-1} \cdot \mathrm{kg}^{-1} \mathrm{IV}\right.$ ), and etomidate (up to $0.3 \mathrm{mg}^{-1} \cdot \mathrm{kg}^{-1} \mathrm{IV}$ ) and maintained with propofol $\left(1.5 \sim 3 \mathrm{mg} \cdot \mathrm{kg}^{-1} \cdot \mathrm{h}^{-1}\right)$ and remifentanil $\left(0.1 \sim 0.2 \mu \mathrm{g} \cdot \mathrm{kg}^{-1} \cdot \mathrm{min}^{-1}\right)$. Neuromuscular blockade was achieved with rocuronium $\left(0.1 \mathrm{mg}^{-1} \cdot \mathrm{kg}^{-1}, \mathrm{IV}\right)$. Following endotracheal intubation, mechanical ventilation was performed without positive end-expiratory pressure using an inspired oxygen concentration of $50 \%$ and tidal volumes of $10 \mathrm{ml}^{-1} \cdot \mathrm{kg}^{-1}$ to maintain an end-expiratory $\mathrm{P}_{\mathrm{ET}} \mathrm{CO}_{2}$ at 4 $\sim 4.5 \mathrm{kPa}$. The patients' lungs were ventilated with a tidal volume of $10 \mathrm{mg}^{-1} \cdot \mathrm{kg}^{-1}$ of ideal body weight and an inspiration and expiration ratio of 1:2.0 with positive-end expiratory pressure (PEEP) of $5 \sim 8 \mathrm{cmH}_{2} \mathrm{O}$. After the final measurement of the assessed variables, the tidal volume was reduced to $8 \mathrm{~mL} / \mathrm{kg}$ of the ideal body weight. The anesthesia was maintained with continuous infusion of remifentanil $\left(0.3 \sim 0.4 \mu \mathrm{g} \cdot \mathrm{kg}^{-1} \cdot \mathrm{min}^{-1}\right)$ and propofol $\left(4 \sim 6 \mathrm{~kg}^{-1} \cdot \mathrm{h}^{-1}\right)$ with bispectral index range between $50 \sim 60$. The arterial pressure waveforms 
were monitored with Phillips Intellivue MP70 monitors (Intellivue MP70, Philips Medical Systems, Suresnes, France). The primary and secondary outcomes were monitored at four intervals of $T_{0}, T_{1}, T_{2}$, and $T_{3}$ corresponding to before induction, $15 \mathrm{~min}$ following anesthesia induction with patient in a supine position, 60 min following surgery, and at the end of the surgery, respectively. At $T_{1}, T_{2}, T_{3}$ timepoints, PPV was measured and recorded. The MAP and HR were recorded at $T_{0}, T_{1}, T_{2}$ and $T_{3}$ timepoints.

All patients were continuouslly prophylacticly infused norepinephrine of $0.030 \mu \mathrm{g} \cdot \mathrm{kg}^{-1} \cdot \mathrm{min}^{-1}, 0.060 \mu \mathrm{g} \cdot \mathrm{kg}^{-}$ ${ }^{1} . \mathrm{min}^{-1}$ and $0.090 \mu \mathrm{g} \cdot \mathrm{kg}^{-1} \cdot \mathrm{min}^{-1}$, respectively before the initiation of general anesthesia. The $\mathrm{RL} 5 \mathrm{ml}^{-1} \cdot \mathrm{kg}^{-}$ ${ }^{1}$ was infused as a bolus volume before general anesthesia induction. Then, the infusion rate was reduced to keep the vein open following endotracheal intubation. If PPV was less than $13 \%$, the maintenance volume of RL was infused at a rate of $2 \mathrm{ml}^{-\mathrm{kg}^{-1}}$. $\mathrm{h}^{-1}$. If PPV was more than $13 \%$, the hydroxyethyl starch (HES, $130 / 0.4$, Voluven) of $3 \mathrm{ml}^{-1} \cdot \mathrm{kg}^{-1}$ (ideal body weight) was infused during $3 \mathrm{~min}$ to test the fluid response to guide the individual fluid therapy. A PPV less than $13 \%$ was defined as the negative fluid responsiveness. If PPV was within the target range and MAP was below the baseline, the ephedrine $5 \sim 10 \mathrm{mg}$ was started and the case was excluded. If PPV was within the target range and MAP was $>20 \%$ of the baseline, $12.5 \sim$ $25 \mathrm{mg}$ urapidil was administered. If PPV was within the target range and blood pressure fluctuated within $20 \%$ of the base blood pressure, norepinephrine infusion was continued until 5 min after sewing.

The day before surgery, all patients were instructed on the use of a 10-point numeric rating scale to assess their pain intensity $(0=$ no pain, $10=$ worst possible pain). Postoperative patient- controlled intravenous analgesia was performed with sufentanil $\left(1.5 \mu \mathrm{g}^{-1} \cdot \mathrm{kg}^{-1}\right)$ combined with ondansetron $8 \mathrm{mg}$. All patients received a basal dose of $\left(0.015 \mu \mathrm{g} \cdot \mathrm{kg}^{-1} \cdot \mathrm{h}^{-1}\right)$ and PCA $\left(0.030 \mu \mathrm{g}^{-1} \cdot \mathrm{kg}^{-1}\right)$. The interval time was set at $10 \mathrm{~min}$, and patient-controlled intravenous analgesia was maintained up to $72 \mathrm{~h}$ following surgery to make sure all patient numeric rating scale scores were below 3 .

\section{Data Collection}

Demographic data, including age, gender, body mass index, duration of surgery, American Society of Anesthesiologists grade and perioperative complications were recorded. The mean blood pressure and heart rate were monitored and recorded at baseline (before induction), $15 \mathrm{~min}$ following anesthesia induction with the patient in a supine position, 60 min following incision and at the end of the surgery. The PPV was recorded at $15 \mathrm{~min}$ following anesthesia induction with the patient in a supine position, 60 min following surgery, and at the end of the surgery. The surgical indices, including blood loss, urine output, autologous blood transfusion and fluid infusion volume (crystalloids and colloids) were recorded. The bradycardia, atropine requirements, intraoperative hypotension and hypertension, postoperative hospital stay were recorded. The incidence of nausea and vomiting, first flatus, first ambulation, first intake timing were selfreported by patients and recorded by a follow-up anesthesiologist who was blinded to group assignments during follow-up.

Our primary outcome was set as the incidence of complications, such as cerebral complications, renal complications, pulmonary complications, cardiac complications and other complications (the incidence of 
fever, wound infection and delayed wound healing). The definition of delayed wound healing was set as the duration of wound healing more than fourteen days. The pulmonary infection, respiratory failure, pulmonary infarction and pulmonary embolism were recorded as pulmonary complications. Acute myocardial injury and acute myocardial infarction were included as cardiac complications. Progressive neurological deficit and acute cerebral infarction were a part of the cerebral complications, and oliguria and acute kidney injury (AKI) were included in the renal complications.

Secondary outcomes included the incidence of intraoperative nausea and vomiting, the frequency of hypertension, the frequency of hypotension, first intake, first flatus, ambulation timing, postoperative hospital stay, the volume of autologous transfusion, the intraoperative blood loss volume, the urine output volume and postoperative hospital stay (days from admission).

The intraoperative hypotension and hypertension were defined as a decrease and increase of $>20 \%$ of the baseline level, respectively. The definition of bradycardia was set as an $\mathrm{HR}<50$ beats/minute (bpm). If the $\mathrm{HR}$ was $<45 \mathrm{bpm}$, atropine bolus $0.3 \sim 0.5 \mathrm{mg}$, depending on the patient's HR, was injected.

\section{Sample Size Calculation}

The sample size was calculated with PASS 2019 Software (Power Analysis and Sample Size). The primary outcome is defined as the incidence of postoperative complications. The preliminary experimental results showed that the incidence of postoperative complications were found in about $40 \%$ of the elderly patients undergoing spinal surgery without norepinephrine infusion, while only $10 \%$ incidence of postoperative complications following prophylactic dosage of $0.060 \mu \mathrm{g} \cdot \mathrm{kg}^{-1} \cdot \mathrm{min}^{-1}$ norepinephrine infusion. At the alpha error of 0.05 , we calculated that eighty seven patients (twenty nine patients/group) would give $80 \%$ power to detect a $20 \%$ absolute reduction in the incidence of postoperative complications in the treatment group. However, to allow the comparisons between the control and each treatment group, the required sample size was assigned as one hundred and eight patients (thirty six patients for each group).

\section{Statistical Analysis}

Statistical Package for Social Science software, version 15 for Microsoft Windows (SPSS Inc., Chicago, IL, USA) was used for data analysis. Categorical data were expressed as frequency (\%). Continuous data were tested for normality and presented as mean (SD) using the Shapiro-Wilk test. The primary outcome (frequency of complications) was analyzed with Fisher's exact test. Continuous data were analyzed with one-way ANOVA. For repeated measures, a two-way repeated-measures ANOVA was used to evaluate the dose (between-groups factor) and time (repeated measures). Post hoc pairwise comparison was performed with an LSD test. A $P$-value $\leq 0.05$ was considered statistically significant.

\section{Results}

A total of one hundred and eight patients were screened for eligibility, of which eighteen subjects were excluded, twelve patients did not meet inclusion criteria, four patients declined to participate the trail, two 
patients were excluded for other reasons. Finally ninety patients $(n=30)$ were selected to undergo the randomization process (Fig. 2). Overall, there are homogeneity in age $(P=0.173)$, Body Mass Index(BMI) $(P$ $=0.085)$, gender $(P=0.843)$, American Society of Anesthesiologists (ASA) grade classification $(P=0.425)$, duration of surgery $(P=0.563)$ and preoperative complications (Table 1$)$.

Table 1

Dose dependedent characteristics of norepinephrine

\begin{tabular}{|c|c|c|c|c|}
\hline & $\begin{array}{l}0.030 \mu \mathrm{g} \cdot \mathrm{kg}^{-1} \cdot \mathrm{min}^{-1} \\
\text { Group }(\mathrm{n}=30)\end{array}$ & $\begin{array}{l}0.060 \mu \mathrm{g} \cdot \mathrm{kg}^{-1} \cdot \mathrm{min}^{-1} \\
\text { Group }(\mathrm{n}=30)\end{array}$ & $\begin{array}{l}0.090 \mu \mathrm{g} \cdot \mathrm{kg}^{-1} \cdot \mathrm{min}^{-1} \\
\text { Group }(\mathrm{n}=30)\end{array}$ & $P$ \\
\hline Age (years) & $67.1 \pm 2.7$ & $68.0 \pm 2.4$ & $66.7 \pm 2.8$ & 0.173 \\
\hline $\mathrm{BMI}\left(\mathrm{kg} / \mathrm{m}^{2}\right)$ & $22.1 \pm 2.1$ & $21.1 \pm 2.4$ & $22.7 \pm 2.1$ & 0.085 \\
\hline Male/Female & $8 / 22$ & $7 / 23$ & $9 / 21$ & 0.843 \\
\hline ASA II/III & $19 / 11$ & $14 / 16$ & $17 / 13$ & 0.425 \\
\hline $\begin{array}{l}\text { Time of surgery } \\
\text { (min) }\end{array}$ & $97.0 \pm 17.1$ & $99.8 \pm 14.2$ & $97.3 \pm 11.0$ & 0.563 \\
\hline \multicolumn{5}{|c|}{ Preoperative complications } \\
\hline Hypertension (\%) & $11(36.7)$ & $10(33.3)$ & $13(43.3)$ & 0.718 \\
\hline Diabetes (\%) & $7(23.3)$ & $6(20)$ & $7(23.3)$ & 0.938 \\
\hline Heart disease (\%) & $6(20)$ & $7(23.3)$ & $7(23.3)$ & 0.938 \\
\hline $\begin{array}{l}\text { Cerebrovascular } \\
\text { disease (\%) }\end{array}$ & $10(33.3)$ & $13(43.3)$ & $11(36.7)$ & 0.718 \\
\hline \multicolumn{5}{|c|}{$\begin{array}{l}\text { Data were expressed as mean (SD), } n(\%) \text {. BMI, body mass index; ASA, American Society of } \\
\text { Anesthesiologist } \\
\text { Patients' characteristics in three dosage of norepinephrine infusion groups. }\end{array}$} \\
\hline
\end{tabular}

There were no significant difference in the incidence of total postoperative complications among three groups $(P>0.05)$. The incidence of delayed wound healing and wound infection were obviously reduced among three groups $(P<0.05)$, especially in the $0.060 \mu \mathrm{g} \cdot \mathrm{kg}^{-1} \cdot \mathrm{min}^{-1}$ and $0.090 \mu \mathrm{g} \cdot \mathrm{kg}^{-1} \cdot \mathrm{min}^{-1}$ dosage compared to the $0.030 \mu \mathrm{g} \cdot \mathrm{kg}^{-1} \cdot \mathrm{min}^{-1}$ dosage $\left(0.030 \mu \mathrm{g} \cdot \mathrm{kg}^{-1} \cdot \mathrm{min}^{-1} v s .0 .060 \mu \mathrm{g} \cdot \mathrm{kg}^{-1} \cdot \mathrm{min}^{-1} v s\right.$. $0.090 \mu \mathrm{g} . \mathrm{kg}^{-1} \cdot \mathrm{min}^{-1}: 33.3 \%$ vs. $10 \%$ vs. $10 \%, P=0.024 ; 26.7 \%$ vs. $6.7 \%$ vs. $6.7 \%, P=0.031$ ) (Table 2 ). 
Table 2

primary outcome and incidence of complications

\begin{tabular}{|c|c|c|c|c|c|c|c|}
\hline & Cohort & & & $P$ & & & \\
\hline & $\begin{array}{l}0.030 \\
\mu \mathrm{g} \cdot \mathrm{kg}^{-} \\
1 \cdot \mathrm{min}^{-1}\end{array}$ & $\begin{array}{l}0.060 \mu \mathrm{g} . \\
\mathrm{kg}^{-1} \cdot \mathrm{min}^{-}\end{array}$ & $\begin{array}{l}0.090 \\
\mu \mathrm{g} \cdot \mathrm{kg}^{-} \\
1 \cdot \mathrm{min}^{-1}\end{array}$ & $\begin{array}{l}0.030 \\
\text { vs. } \\
0.060\end{array}$ & $\begin{array}{l}0.060 \text { vs. } \\
0.090\end{array}$ & $\begin{array}{l}0.030 \\
\text { Vs. } \\
0.090\end{array}$ & Overall \\
\hline & $\begin{array}{l}\text { Group }(n= \\
30)\end{array}$ & $\begin{array}{l}\text { Group }(n= \\
30)\end{array}$ & $\begin{array}{l}\text { Group }(n= \\
30)\end{array}$ & & & & \\
\hline $\begin{array}{l}\text { Total } \\
\text { complications } \\
(\%)\end{array}$ & $6(20)$ & $4(13.3)$ & 5 (16.7) & 0.488 & 0.718 & 0.739 & 0.787 \\
\hline $\begin{array}{l}\text { Cerebral } \\
\text { complications } \\
(\%)\end{array}$ & $1(3.3)$ & $0(0)$ & $1(3.3)$ & - & - & 1 & 0.600 \\
\hline $\begin{array}{l}\text { Renal } \\
\text { complications } \\
(\%)\end{array}$ & $0(0)$ & $0(0)$ & $0(0)$ & - & - & - & - \\
\hline $\begin{array}{l}\text { Pulmonary } \\
\text { complications } \\
\text { (\%) }\end{array}$ & $3(10)$ & $2(6.7)$ & $3(10)$ & 0.640 & 0.640 & 1 & 0.872 \\
\hline $\begin{array}{l}\text { Cardiac } \\
\text { complications } \\
(\%)\end{array}$ & $2(6.7)$ & $2(6.7)$ & $1(3.3)$ & 1 & 0.554 & 0.554 & 0.809 \\
\hline $\begin{array}{l}\text { Wound } \\
\text { infection (\%) }\end{array}$ & $8(26.7)$ & $2(6.7)$ & $2(6.7)$ & 0.038 & 1 & 0.038 & 0.031 \\
\hline Fever (\%) & $5(16.7)$ & $3(10)$ & $2(6.7)$ & 0.448 & 0.640 & 0.228 & 0.690 \\
\hline $\begin{array}{l}\text { Delayed wound } \\
\text { healing (\%) }\end{array}$ & 10(33.3) & $3(10)$ & $3(10)$ & 0.028 & 1 & 0.028 & 0.024 \\
\hline $\begin{array}{l}\text { Data were expres } \\
\text { The primary outc } \\
\left(0.030 \mu \mathrm{g} . \mathrm{kg}^{-1} .\right.\end{array}$ & $\begin{array}{l}\text { las mean } \\
\text { e and incl }\end{array}$ & $\begin{array}{l}n(\%) \\
\text { ce of com, } \\
\text { g. } \mathrm{kg}^{-1} \cdot \mathrm{mil}\end{array}$ & tions in th & losag & nino & inft & groups \\
\hline
\end{tabular}

There were postoperatively earlier first intake and first flatus among three groups' patients $(P<0.01)$, especially enhancing postoperative first intake by 1.4 hours and first flatus by 1.1 hours in the $0.060 \mu \mathrm{ggg}^{-}$ ${ }^{1} \cdot \mathrm{min}^{-1}$ dosage compared to the $0.030 \mu \mathrm{g} \cdot \mathrm{kg}^{-1} \cdot \mathrm{min}^{-1}$ dosage $(P<0.01)$. Overall, postoperative hospital stay was reduced by around 1 days in the $0.060 \mu \mathrm{g} \cdot \mathrm{kg}^{-1} \cdot \mathrm{min}^{-1}$ dosage and $0.090 \mu \mathrm{g} \cdot \mathrm{kg}^{-1} \cdot \mathrm{min}^{-1}$ dosage groups compared to $0.030 \mu \mathrm{g} \cdot \mathrm{kg}^{-1} \cdot \mathrm{min}^{-1}$ dosage group $\left(0.030 \mu \mathrm{g} \cdot \mathrm{kg}^{-1} \cdot \mathrm{min}^{-1} v s .0 .060 \mu \mathrm{g} \cdot \mathrm{kg}^{-1} \cdot \mathrm{min}^{-1} v s\right.$. $\left.0.090 \mu \mathrm{g} \cdot \mathrm{kg}^{-1} \cdot \mathrm{min}^{-1}: 7.1 \mathrm{vs} .6 .0 \mathrm{vs} .6 .2, P=0.066\right)$. There were no significant difference in the incidence of nausea and vomiting among three groups (Table 3 ). 
Table 3

Dose dependend Postoperative outcome

\begin{tabular}{|c|c|c|c|c|c|c|c|}
\hline & Cohort & & & $P$ & & & \\
\hline & $\begin{array}{l}0.030 \mu \mathrm{g} \cdot \mathrm{kg}^{-} \\
1 \cdot \min ^{-1} \\
\text { Group }(\mathrm{n}= \\
30)\end{array}$ & $\begin{array}{l}0.060 \mu \mathrm{g} \cdot \mathrm{kg}^{-} \\
1 \cdot \min ^{-1} \\
\text { Group }(\mathrm{n}= \\
30)\end{array}$ & $\begin{array}{l}0.090 \mu \mathrm{g} \cdot \mathrm{kg}^{-} \\
1 \cdot \min ^{-1} \\
\text { Group }(\mathrm{n}= \\
30)\end{array}$ & $\begin{array}{l}0.030 \\
V s . \\
0.060\end{array}$ & $\begin{array}{l}0.060 \\
V S . \\
0.090\end{array}$ & $\begin{array}{l}0.030 \text { vs. } \\
0.090\end{array}$ & Overall \\
\hline $\begin{array}{l}\text { Nausea and } \\
\text { vomiting (\%) }\end{array}$ & $8(26.7)$ & $6(20)$ & $7(23.2)$ & 0.761 & 1.000 & 0.761 & 0.830 \\
\hline $\begin{array}{l}\text { Time of first } \\
\text { flatus (h) }\end{array}$ & $5.9 \pm 0.8$ & $4.8 \pm 1.4$ & $5.1 \pm 1.5$ & 0.003 & 0.562 & 0.053 & 0.004 \\
\hline $\begin{array}{l}\text { Time of first } \\
\text { ambulation } \\
\text { (h) }\end{array}$ & $50.5 \pm 12.7$ & $48.9 \pm 8.9$ & $48.6 \pm 8.7$ & 0.818 & 0.994 & 0.762 & 0.749 \\
\hline $\begin{array}{l}\text { Time of first } \\
\text { intake }\end{array}$ & $6.8 \pm 1.3$ & $5.4 \pm 1.9$ & $5.8 \pm 1.9$ & 0.007 & 0.647 & 0.072 & 0.008 \\
\hline $\begin{array}{l}\text { Postoperative } \\
\text { hospital } \\
\text { stays (d) }\end{array}$ & $7.1 \pm 2.3$ & $6.0 \pm 2.0$ & $6.2 \pm 1.3$ & 0.073 & 0.914 & 0.17 & 0.066 \\
\hline
\end{tabular}

Postoperative outcome in three dosage of norepinephrine infusion groups $\left(0.030 \mu \mathrm{g} \cdot \mathrm{kg}^{-1} \cdot \mathrm{min}^{-1} \mathrm{vs}\right.$. $0.060 \mu \mathrm{g} \cdot \mathrm{kg}^{-1} \cdot \mathrm{min}^{-1}$ vs. $0.090 \mu \mathrm{g} \cdot \mathrm{kg}^{-1} \cdot \mathrm{min}^{-1}$ )

The patients in the $0.060 \mu \mathrm{g} \cdot \mathrm{kg}^{-1} \cdot \mathrm{min}^{-1}$ and $0.090 \mu \mathrm{g} \cdot \mathrm{kg}^{-1} \cdot \mathrm{min}^{-1}$ dosage groups had higher MAP compared to the $0.030 \mu \mathrm{g} \cdot \mathrm{kg}^{-1} \cdot \mathrm{min}^{-1}$ dosage group at the $\mathrm{T}_{2}(P<0.05)$ and $\mathrm{T}_{3}$ timepoints $(P<0.01)$. The incidence of intraoperative hypotension in the 0.060 and $0.090 \mu \mathrm{g} \cdot \mathrm{kg}^{-1} \cdot \mathrm{min}^{-1}$ dosages of norepinephrine infusion groups were effectively decreased compared to the $0.030 \mu \mathrm{g} \cdot \mathrm{kg}^{-1} \cdot \mathrm{min}^{-1}$ dosage $(P<0.01)$ at $\mathrm{T}_{1}, \mathrm{~T}_{2}$, $\mathrm{T}_{3}$ timepoints. Intraoperative infusion of crystalloids, colloids and total fluid volume in the $0.030 \mu \mathrm{g} . \mathrm{kg}^{-}$ ${ }^{1} . \mathrm{min}^{-1}$ dosage group were more higher than that in the 0.060 and $0.090 \mu \mathrm{g} \cdot \mathrm{kg}^{-1} \cdot \mathrm{min}^{-1}$ dosages of norepinephrine infusion groups $(P<0.01)$. The elderly patients in $0.090 \mu \mathrm{g} \cdot \mathrm{kg}^{-1} \cdot \mathrm{min}^{-1}$ dosage group had obviously lower heart rate than that in the $0.060 \mu \mathrm{g} \cdot \mathrm{kg}^{-1} \cdot \mathrm{min}^{-1}$ dosage and $0.030 \mu \mathrm{g} \cdot \mathrm{kg}^{-1} \cdot \mathrm{min}^{-1}$ groups $(P$ $<0.05)$. The frequency of bradycardia in the $0.090 \mu \mathrm{g} \cdot \mathrm{kg}^{-1} \cdot \mathrm{min}^{-1}$ dosage group's patients was obviously more than that in the $0.030 \mu \mathrm{g} \cdot \mathrm{kg}^{-1} \cdot \mathrm{min}^{-1}$ group's patients and $0.060 \mu \mathrm{g} \cdot \mathrm{kg}^{-1} \cdot \mathrm{min}^{-1}$ group's patients $(P<$ 0.05). Patients' frequentcy requiring atropine injection in the $0.090 \mu \mathrm{g} \cdot \mathrm{kg}^{-1} \cdot \mathrm{min}^{-1}$ dosage group was significantly elevated than that in the $0.030 \mu \mathrm{g} \cdot \mathrm{kg}^{-1} \cdot \mathrm{min}^{-1}$ dosage and $0.060 \mu \mathrm{g} \cdot \mathrm{kg}^{-1} \cdot \mathrm{min}^{-1}$ dosage groups $(P<0.01)$ (Table 4 and Table 5). 
Table 4

Intraoperative hemodynamic parameters

Cohort

\begin{tabular}{|c|c|c|c|c|c|c|c|c|}
\hline & & $\begin{array}{l}0.030 \mu \mathrm{g} \cdot \mathrm{kg}^{-} \\
1 \cdot \mathrm{min}^{-1} \\
\text { Group (n = } \\
30)\end{array}$ & $\begin{array}{l}0.060 \mu \mathrm{g} \cdot \mathrm{kg}^{-} \\
1 \cdot \mathrm{min}^{-} \mathrm{Group} \\
(\mathrm{n}=30)\end{array}$ & $\begin{array}{l}0.090 \mu \mathrm{g} \cdot \mathrm{kg}^{-} \\
1 \cdot \mathrm{min}^{-1} \\
\text { Group (n = } \\
30)\end{array}$ & $\begin{array}{l}0.030 \text { vs. } \\
0.060\end{array}$ & $\begin{array}{l}0.060 v s . \\
0.090\end{array}$ & $\begin{array}{l}0.030 \text { vs. } \\
0.090\end{array}$ & overall \\
\hline \multirow[t]{4}{*}{ MAP } & $\mathrm{T}_{0}$ & $98.3 \pm 6.5$ & $98.1 \pm 8.1$ & $100.6 \pm 7.2$ & 0.888 & 0.183 & 0.233 & 0.342 \\
\hline & $\mathrm{T}_{1}$ & $71.8 \pm 7.7$ & $73.6 \pm 7.8$ & $72.4 \pm 7.8$ & 0.390 & 0.563 & 0.778 & 0.680 \\
\hline & $\mathrm{T}_{2}$ & $56.9 \pm 7.4^{\star} *$ & $62.2 \pm 7.9$ & $63.3 \pm 6.9$ & 0.014 & 0.615 & 0.003 & 0.007 \\
\hline & $\mathrm{T}_{3}$ & $75.2 \pm 7.6^{*} *$ & $81.2 \pm 8.1$ & $81.5 \pm 7.7$ & 0.005 & 0.830 & 0.003 & 0.004 \\
\hline \multirow[t]{4}{*}{$\mathrm{HR}$} & $\mathrm{T}_{0}$ & $72.0 \pm 8.0$ & $74.3 \pm 6.7$ & $71.7 \pm 6.9$ & 0.228 & 0.178 & 0.887 & 0.334 \\
\hline & $\mathrm{T}_{1}$ & $63.3 \pm 4.8$ & $62.7 \pm 6.1$ & $57.1 \pm 3.1$ & 0.629 & 0.001 & 0.001 & 0.001 \\
\hline & $\mathrm{T}_{2}$ & $72.0 \pm 8.6$ & $68.8 \pm 7.6$ & $62.3 \pm 7.3$ & 0.114 & 0.002 & 0.001 & 0.001 \\
\hline & $\mathrm{T}_{3}$ & $74.5 \pm 9.5$ & $73.7 \pm 9.0$ & $69.3 \pm 7.0$ & 0.740 & 0.048 & 0.022 & 0.045 \\
\hline \multirow[t]{3}{*}{ PPV } & $\mathrm{T}_{1}$ & $12.7 \pm 1.7$ & $12.5 \pm 1.9$ & $12.2 \pm 1.1$ & 0.740 & 0.508 & 0.322 & 0.599 \\
\hline & $\mathrm{T}_{2}$ & $12.3 \pm 1.7$ & $11.5 \pm 1.2$ & $11.4 \pm 1.3$ & 0.233 & 0.927 & 0.199 & 0.357 \\
\hline & $\mathrm{T}_{3}$ & $8.3 \pm 0.8$ & $8.0 \pm 1.6$ & $8.2 \pm 0.9$ & 0.296 & 0.513 & 0.695 & 0.571 \\
\hline
\end{tabular}

Data were expressed as mean $\pm S D$. $n(\%)$.

Intraoperative hemodynamic parameters' trend in three dosage of norepinephrine infusion groups $\left(0.030 \mu \mathrm{g} \cdot \mathrm{kg}^{-1} . \mathrm{min}^{-1}\right.$ vs. $0.060 \mu \mathrm{g} \cdot \mathrm{kg}^{-1} \cdot \mathrm{min}^{-1}$ vs. $\left.0.090 \mu \mathrm{g} \cdot \mathrm{kg}^{-1} . \mathrm{min}^{-1}\right)$ 
Table 5

Intraoperative basic materials and morbidity

\begin{tabular}{|c|c|c|c|c|c|c|c|}
\hline & $\begin{array}{l}0.030 \mu \mathrm{g} \cdot \mathrm{kg}^{-} \\
1 \cdot \min ^{-1} \\
\text { Group }(\mathrm{n}= \\
30)\end{array}$ & $\begin{array}{l}0.060 \mu \mathrm{g} \cdot \mathrm{kg}^{-} \\
1 \cdot \min ^{-1} \\
\text { Group (n = } \\
30)\end{array}$ & $\begin{array}{l}0.090 \mu \mathrm{gg} \text { kg- } \\
{ }^{1} \cdot \mathrm{min}^{-}{ }^{1} \text { Group (n } \\
=30)\end{array}$ & $\begin{array}{l}0.030 \\
\text { vs. } \\
0.060\end{array}$ & $\begin{array}{l}0.060 \\
\text { vs. } \\
0.090\end{array}$ & $\begin{array}{l}0.030 \\
\text { vs. } \\
0.090\end{array}$ & Overall \\
\hline $\begin{array}{l}\text { Total } \\
\text { fluid volume }\end{array}$ & $\begin{array}{l}1522.9 \pm \\
138.2\end{array}$ & $\begin{array}{l}1340.2 \pm \\
240.2\end{array}$ & $1352.1 \pm 298.1$ & 0.001 & 0.076 & 0.001 & 0.005 \\
\hline Crystalloid & $\begin{array}{l}1035.1 \pm \\
236.4\end{array}$ & $\begin{array}{l}883.2 \pm \\
208.1\end{array}$ & $838.3 \pm 231.1$ & 0.029 & 0.721 & 0.003 & 0.003 \\
\hline Colloid & $\begin{array}{l}610.2 \pm \\
180.2\end{array}$ & $\begin{array}{l}475.2 \pm \\
206.7\end{array}$ & $467.8 \pm 205.2$ & 0.026 & 0.989 & 0.018 & 0.01 \\
\hline $\begin{array}{l}\text { Autologous } \\
\text { blood } \\
\text { transfusion }\end{array}$ & $104.2 \pm 45.8$ & $101.8 \pm 44.4$ & $83.6 \pm 26.8$ & 0.971 & 0.185 & 0.117 & 0.096 \\
\hline Blood loss & $\begin{array}{l}278.6 \pm \\
128.7\end{array}$ & $\begin{array}{l}241.3 \pm \\
119.3\end{array}$ & $226.6 \pm 71.6$ & 0.387 & 0.862 & 0.163 & 0.171 \\
\hline Urine output & $\begin{array}{l}680.5 \pm \\
253.1\end{array}$ & $\begin{array}{l}651.1 \pm \\
246.4\end{array}$ & $603.2 \pm 262.9$ & 0.895 & 0.797 & 0.980 & 0.805 \\
\hline $\begin{array}{l}\text { Intraoperative } \\
\text { hypotension } \\
(\%)\end{array}$ & $10(33.3)$ & $2(6.7)$ & $1(3.3)$ & 0.01 & 0.554 & 0.003 & 0.001 \\
\hline $\begin{array}{l}\text { Bradycardia } \\
(\%)\end{array}$ & $1(3.3)$ & $2(6.7)$ & $8(26.7)$ & 0.554 & 0.038 & 0.026 & 0.012 \\
\hline $\begin{array}{l}\text { Intraoperative } \\
\text { hypertension } \\
(\%)\end{array}$ & 0 & 0 & $1(3.3)$ & - & 1 & 1 & 0.364 \\
\hline $\begin{array}{l}\text { Atropine } \\
\text { requirements } \\
\text { (mg) }\end{array}$ & $0.1 \pm 0.2$ & $0.1 \pm 0.1$ & $0.3 \pm 0.3$ & 0.369 & 0.001 & 0.005 & 0.001 \\
\hline \multicolumn{8}{|c|}{$\begin{array}{l}\text { Data were expressed as mean } \pm S D . n(\%) \\
\text { Intraoperative basic materials and morbidity in three dosage of norepinephrine infusion groups } \\
\left(0.030 \mu \mathrm{g} \cdot \mathrm{kg}^{-1} \cdot \mathrm{min}^{-1} \text { vs. } 0.060 \mu \mathrm{g} \cdot \mathrm{kg}^{-1} \cdot \mathrm{min}^{-1} v s .0 .090 \mu \mathrm{g} \cdot \mathrm{kg}^{-1} \cdot \mathrm{min}^{-1}\right)\end{array}$} \\
\hline
\end{tabular}

\section{Discussion}

With advances in public health and continued medical progress, the elderly has been a fast-growing segment of the population [7]. This will lead to a proportional increase in age-related diseases such as lumbar disc herniation, stenosis and spondylolisthesis. However, the elderly population, especially those older than 80 years, are more likely to have a higher comorbidity and osteoporosis burden, often with multiple systems involved [8]. The complexity of the health status may increase the risks of complications, poor functional outcomes and mortality after surgery in patients aged 80 years and older [9].It is well established that perioperative fluid management influences postoperative complication rates. However, the 
optimal intraoperative fluid regimen is still controversial.Especially in including use of vasopressors, or a goal-directed hemodynamic therapy [10]. In order to improve the quality of postoperative recovery and shorten hospital stays, many efforts are made to facilitate the early return to normal organ function.

Norepinephrine is a vasopressor with potent $\alpha$-adrenergic agonistic activity in addition to some $\beta$-adrenergic agonistic activity; thus, it has been suggested as an alternative to phenylephrine that would not compromise the cardiac function. This makes norepinephrine a possible choice for elderly patients with relative contraindications of phenylephrine, such as low baseline HR or poor cardiac function. We did not include such patients because of the monitoring indicators- PPV, which was not suitable for patients with arrhythmias [3]. Currently, studies are exploring the optimum single dose for use as a continuous infusion rate during other surgeries in elderly patients.

Norepinephrine is currently a novel option for the prevention and treatment of hypotension, and to the best of our knowledge, this is the first study to determine the optimal infusion rate of norepinephrine, which in any format manages hypotension and avoids fluid overload complications during general anesthesia for spinal surgery. However, there may be some concern about the administration of norepinephrine via peripheral veins. Significant morbidity was not demonstrated in a recent study wherein norepinephrine infusions were administered in hypotensive patients for an average of $32 \mathrm{~h}$ at a maximal rate of $30 \mu \mathrm{g} \cdot \mathrm{min}^{-}$ 1 via 18-gauge and 20-gauge cannulate in the antecubital fossa, dorsum of the hand, and forearm flexor veins. Minor complications (extravasation) occurred at a rate of 5.45\% [11]. Previous studies demonstrated that extravasation was observed in the veins distal to the antecubital fossa or in the feet, and recent reports suggested that placement within a large proximal vein might be preferred $[12,13]$. Moreover, the drug manufacturer does not specify that norepinephrine needs to be administered centrally, rather via a large vein, preferably antecubital and avoiding the lower extremities [14]. Furthermore, in this study, the small infusion rate of norepinephrine $(8 \mu \mathrm{g} / \mathrm{mL})$ was used. Therefore, the risk of any local tissue injury was minimal, and we did not observe any adverse effects.

Hasanin et al reported both the $0.050 \mu \mathrm{g} \cdot \mathrm{kg}^{-1} \cdot \mathrm{min}^{-1}$ and $0.075 \mu \mathrm{g} \cdot \mathrm{kg}^{-1} \cdot \mathrm{min}^{-1}$ norepinephrine infusion rates effectively reduced the post-spinal hypotension during cesarean delivery as compared to the $0.025 \mu \mathrm{g}^{\cdot \mathrm{kg}^{-}}$ ${ }^{1} \cdot \mathrm{min}^{-1}$ infusion rate [15]. Kee et al. investigated the efficacy of manually titrated prophylactic norepinephrine infusion for maintaining the blood pressure during spinal anesthesia for elective cesarean delivery. The study reported that for these patients, a manually titrated infusion of $5 \mu \mathrm{g} \cdot \mathrm{ml}^{-1}$ of norepinephrine is effective for maintaining blood pressure and decreasing the incidence of hypotension without significant adverse events on the neonatal outcome [16]. The middle dose reported by the previously conducted studies $\left(0.060 \mu \mathrm{g} \cdot \mathrm{kg}^{-1} \cdot \mathrm{min}^{-1}\right)$ was used in the current study.

Although a significant reduction in the heart rate was observed in all groups as compared to the baseline reading. Especially $\mathrm{n}$ the higher doses, a few cases experienced marked bradycardia requiring atropine: $1(3 \%)$ case in the $0.030 \mu \mathrm{g} \cdot \mathrm{kg}^{-1} \cdot \mathrm{min}^{-1}$ group, $2(6.7 \%)$ in the $0.060 \mu \mathrm{g} \cdot \mathrm{kg}^{-1} \cdot \mathrm{min}^{-1} \mathrm{group}$, and $8(26 \%)$ in the $0.090 \mu \mathrm{g} \cdot \mathrm{kg}^{-1} \cdot \mathrm{min}^{-1}$ group. Thus, we speculated that norepinephrine could be the appropriate vasopressor in elderly patients with low baseline HR. We did not measure the patients' cardiac output; however, it has 
been recently suggested that monitoring the HR could be used as a potential surrogate for cardiac output [17]. Furthermore, only a few cases of intraoperative hypertension were observed in the three study groups. These events were transient and resolved by stopping the fluid infusion. However, this side effect could not be evaluated in this study.

Our primary outcome was the incidence of complications (cerebral complications, renal complications, pulmonary complications, and cardiac complications). The two higher dose groups had fewer complications but not statistically significant, which might be attributed to the anesthesiologists' concern about the elderly patients with more complications, poor organ reserve function, and reduced tolerance to cyclic fluctuation; during anesthesia management, attention is paid to maintaining perfusion pressure to ensure the perfusion of critical organs. We used a continuous infusion rate of norepinephrine before starting the anesthesia. Our hypothesis was based on a previous study, which reported that the use of a prophylactic bolus of phenylephrine before starting infusion was beneficial [18]. Herein, we hypothesized that the prophylactic administration of norepinephrine could increase the peripheral vascular resistance, reduce the amount of fluid required to achieve goal-directed fluid therapy, and accelerate the rehabilitation process of elderly patients.

The prone position increases abdominal pressure, which results in reduced venous return and lung compliance. Yu et al. reported that high predictability of PPV, remained as useful indices for guiding fluid therapy in prone patients with minimal alterations in the optimal cutoff values to predict fluid responsiveness [19]. Compared to the SVV, PPV does not require additional kits and can reduce the patients'financial burden and the accuracy is similar [20]. However,some researchers questioned the accuracy of the predicted volume of PPV in the prone position. Biais et al. reported that prone position induces a significant increase in PPV and SVV but does not alter their abilities to predict the responsiveness of the fluid [21]. The 13\% PPV threshold value was also based on previous studies. Nevertheless, There were several possible limitations to the present study. We did not use advanced hemodynamic monitors for cardiac output and peripheral vascular resistance .Also, The volume status of elderly patients suffering from lumbar disk herniation or lumbar spondylolisthesis were different.In future study,more attention should be paid on perioperative endothelial function,espcially the relationship between perioperative complications and syndecan-1.

\section{Conclusion}

In conclusion, the dosage $0.060 \mu \mathrm{g} \cdot \mathrm{kg}^{-1} \cdot \mathrm{min}^{-1}$ of norepinephrine infusion combined with goal-directed fluid therapy (PPV) is more suitable for elderly patients' intraoperative management undergone lumbar spinal fusion during general anesthesia. It can improve the elderly patients' postoperative outcome and accelerate their rehabilitation process by decreasing the incidence of intraoperative hypotentsion, bradycardia and fluid overloading risk.

\section{Abbreviations}


PPV: Pulse pressure variation; MAP: mean arterial pressure; ECG: Electro cardio graph; HES: hydroxyethyl starch; PEEP: positive-end expiratory pressure; BMI: Body Mass Index; ASA: American Society of Anesthesiologists.

\section{Declarations}

\section{Acknowledgements:}

The authors are thankful to the technical stuff of Affiliated Hospital of Inner Mongolia Medical University. This study was supported by the Natural Science foundation of Inner Mongolia autonomous region (2019MS08129),Beijing Municipal Administration of Hospitals Clinical Medicine Development of Special Funding Support (ZYLX201813).

\section{Authors contributions:}

conceptualization, Tianlong Wang and Fan Wu; methodology, Tianlong Wang.; software, Tao Liang; validation, Tianlong Wang., Fan Wu.; formal analysis, Tao Liang investigation, Fan Wu ; resources, Yanhui Ma and Jie Wu ; data curation, Tao Liang; writing-original draft preparation, Long Fan and Huiqun Fu; writing-review and editing, Fan Wu ; visualization, Wei Xiao.; supervision, Fan Wu.; project administration, Wei Xiao.; funding acquisition, Tianlong Wang

\section{Availability of data and materials:}

The data that support the fndings of this study are available in anonymized form from the corresponding author on reasonable request and after agreement with the local ethics committee.

\section{Ethics approval and consent to participate:}

This study was approved by the ethics committee of the Capital Medical University, Beijing and Affiliated Hospital of Inner Mongolia Medical University. Written informed consent to participate and consent to publish was obtained and signed from each patient.

\section{Consent for publication:}

Not applicable.

\section{Competing interests:}

The authors declare that they have no conflict of interest. 


\section{Funding:}

This study was supported by the Natural Science foundation of Inner Mongolia autonomous region (2019MS08129),Beijing Municipal Administration of Hospitals Clinical Medicine Development of Special Funding Support (ZYLX201813).

\section{References}

1. Akyol O, Reis C, Reis H, Zhang J, Cheng S, Applegate RL: Anesthesia for Traumatic Spine Injury. In: Textbook of Neuroanesthesia and Neurocritical Care: Volume I - Neuroanesthesia. edn. Edited by Prabhakar H, Ali Z. Singapore: Springer Singapore; 2019: 225-231.

2. Salzwedel C, Puig J, Carstens A, Bein B, Molnar Z, Kiss K, Hussain A, Belda J, Kirov MY, Sakka SG et al: Perioperative goal-directed hemodynamic therapy based on radial arterial pulse pressure variation and continuous cardiac index trending reduces postoperative complications after major abdominal surgery: a multi-center, prospective, randomized study. Critical care (London, England) 2013, 17(5):R191.

3. Bennett VA, Cecconi M: Perioperative fluid management: From physiology to improving clinical outcomes. Indian journal of anaesthesia 2017, 61(8):614-621.

4. Chappell D, Jacob M: Role of the glycocalyx in fluid management: Small things matter. Best practice \& research Clinical anaesthesiology 2014, 28(3):227-234.

5. Yang X, Du B: Does pulse pressure variation predict fluid responsiveness in critically ill patients? A systematic review and meta-analysis. Critical care (London, England) 2014, 18(6):650.

6. Hasanin A, Mokhtar AM, Badawy AA, Fouad R: Post-spinal anesthesia hypotension during cesarean delivery, a review article. Egyptian Journal of Anaesthesia 2017, 33(2):189-193.

7. Fehlings MG, Tetreault L, Nater A, Choma T, Harrop J, Mroz T, Santaguida C, Smith JS: The Aging of the Global Population: The Changing Epidemiology of Disease and Spinal Disorders. Neurosurgery 2015, 77 Suppl 4:S1-5.

8. Nagashima H, Dokai T, Hashiguchi H, Ishii H, Kameyama Y, Katae Y, Morio Y, Morishita T, Murata M, Nanjo $Y$ et al: Clinical features and surgical outcomes of cervical spondylotic myelopathy in patients aged $\mathbf{8 0}$ years or older: a multi-center retrospective study. European spine journal : official publication of the European Spine Society, the European Spinal Deformity Society, and the European Section of the Cervical Spine Research Society 2011, 20(2):240-246.

9. Galiano K, Obwegeser AA, Gabl MV, Bauer R, Twerdy K: Long-term outcome of laminectomy for spinal stenosis in octogenarians. Spine 2005, 30(3):332-335.

10. Wuethrich PY, Burkhard FC, Thalmann GN, Stueber F, Studer UE: Restrictive Deferred Hydration Combined with Preemptive Norepinephrine Infusion during Radical Cystectomy Reduces Postoperative Complications and Hospitalization Time: A Randomized Clinical Trial. Anesthesiology: The Journal of the American Society of Anesthesiologists 2014, 120(2):365-377.

11. Medlej K, Kazzi AA, El Hajj Chehade A, Saad Eldine M, Chami A, Bachir R, Zebian D, Abou Dagher G: Complications from Administration of Vasopressors Through Peripheral Venous Catheters: An 
Observational Study. The Journal of emergency medicine 2018, 54(1):47-53.

12. Perlow S, Shapiro RA: Skin necrosis following intravenous use of norepinephrine; report of six cases. American journal of surgery 1956, 92(4):566-570.

13. Humphreys J, Johnston JH, Richardson JC: Skin necrosis following intravenous noradrenaline. British medical journal 1955, 2(4950):1250-1252.

14. Loubani OM, Green RS: A systematic review of extravasation and local tissue injury from administration of vasopressors through peripheral intravenous catheters and central venous catheters. Journal of critical care 2015, 30(3):653.e659-617.

15. Hasanin AM, Amin SM, Agiza NA, Elsayed MK, Refaat S, Hussein HA, Rouk TI, Alrahmany M, Elsayad $\mathrm{ME}$, Elshafaei KA et al: Norepinephrine Infusion for Preventing Postspinal Anesthesia Hypotension during Cesarean Delivery: A Randomized Dose-finding Trial. Anesthesiology 2019, 130(1):55-62.

16. Heesen M, Kolhr S, Rossaint R, Straube S: Prophylactic phenylephrine for caesarean section under spinal anaesthesia: systematic review and meta-analysis. Anaesthesia 2014, 69(2):143-165.

17. Ngan Kee WD, Lee SWY, Ng FF, Khaw KS: Prophylactic Norepinephrine Infusion for Preventing Hypotension During Spinal Anesthesia for Cesarean Delivery. Anesthesia and analgesia 2018, 126(6):1989-1994.

18. Vallejo MC, Attaallah AF, Elzamzamy OM, Cifarelli DT, Phelps AL, Hobbs GR, Shapiro RE, Ranganathan $\mathrm{P}$ : An open-label randomized controlled clinical trial for comparison of continuous phenylephrine versus norepinephrine infusion in prevention of spinal hypotension during cesarean delivery. International journal of obstetric anesthesia 2017, 29:18-25.

19. Rathore A, Singh S, Lamsal R, Taank P, Paul D: Validity of Pulse Pressure Variation (PPV) Compared with Stroke Volume Variation (SVV) in Predicting Fluid Responsiveness. Turkish journal of anaesthesiology and reanimation 2017, 45(4):210-217.

20. Yu Y, Annala AJ, Barrio JR, Toyokuni T, Satyamurthy N, Namavari M, Cherry SR, Phelps ME, Herschman HR, Gambhir SS: Quantification of target gene expression by imaging reporter gene expression in living animals. Nature medicine 2000, 6(8):933-937.

21. Biais M, Bernard O, Ha JC, Degryse C, Sztark F: Abilities of pulse pressure variations and stroke volume variations to predict fluid responsiveness in prone position during scoliosis surgery. British journal of anaesthesia 2010, 104(4):407-413.

\section{Figures}




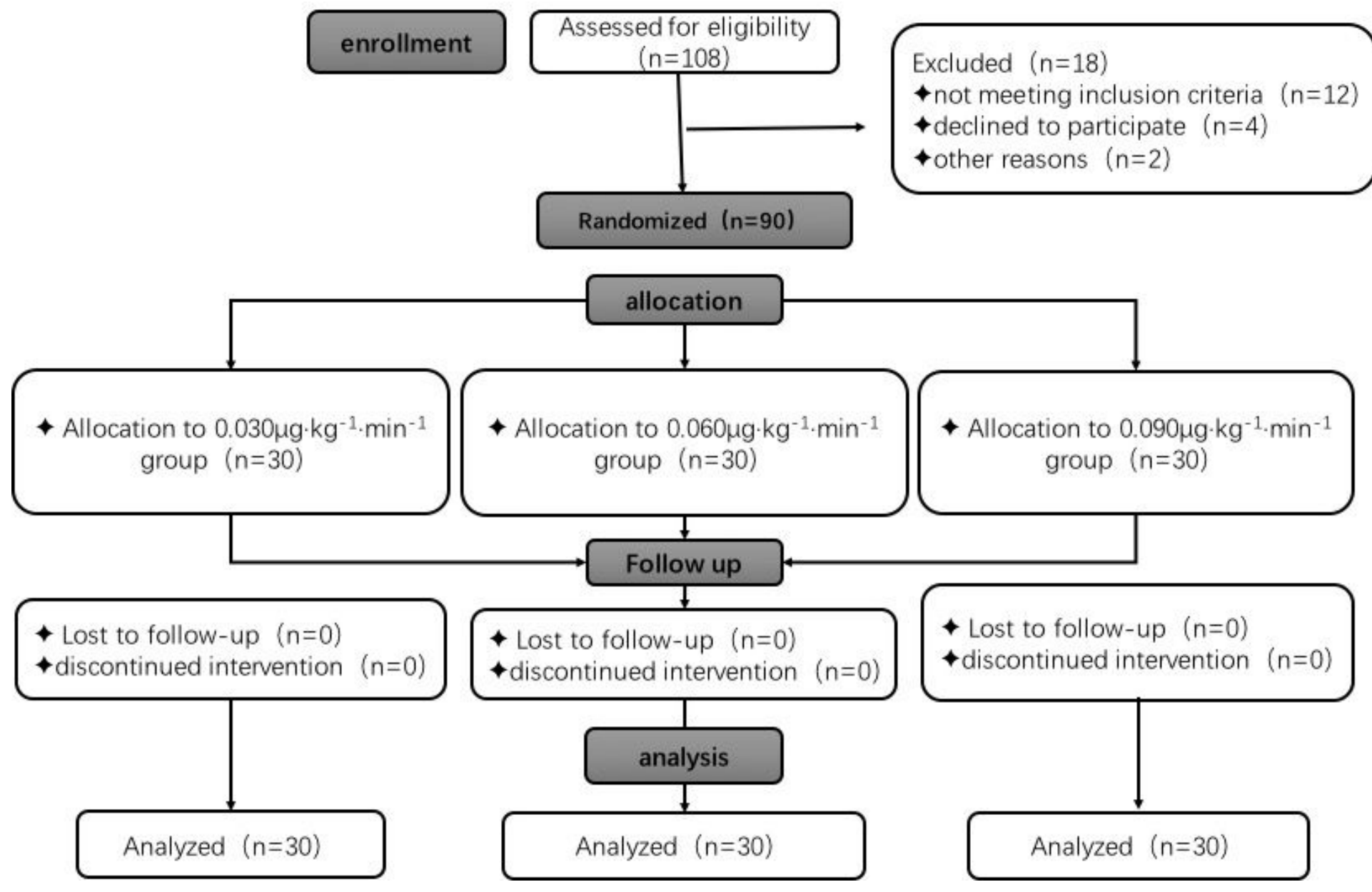

Figure 1

Schematic protocol of intraoperative management. Schematic chart showing the three dosages of norepinephrine infusion groups $(0.030 \mu \mathrm{g} . \mathrm{kg}-1 . \mathrm{min}-1$ vs. $0.060 \mu \mathrm{g} . \mathrm{kg}-1 . \mathrm{min}-1$ vs. $0.090 \mu \mathrm{g} . \mathrm{kg}-1 . \mathrm{min}-1)$ 


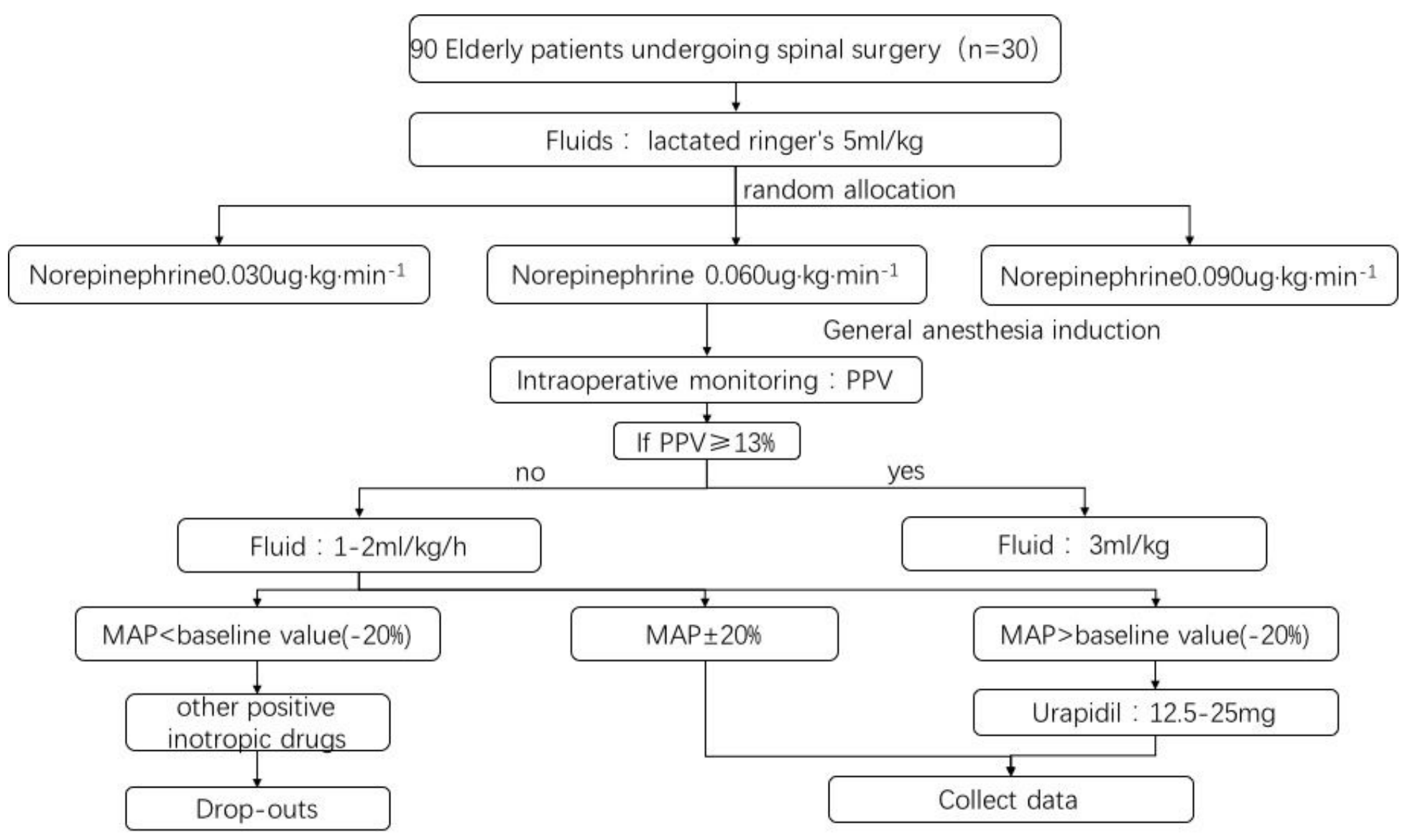

\section{Figure 2}

Patients' fluid management flowchart. Chart shows the three dosages of norepinephrine infusion groups $(0.030 \mu \mathrm{g} . \mathrm{kg}-1 . \mathrm{min}-1 \mathrm{vs.} 0.060 \mu \mathrm{g} . \mathrm{kg}-1 . \mathrm{min}-1$ vs. $0.090 \mu \mathrm{g} . \mathrm{kg}-1 . \mathrm{min}-1)$. 